\title{
Inconsistencies - The German Federal Constitutional Court on the European Arrest Warrant
}

\author{
Christian Tomuschat*
}

Features European Arrest Warrant - Article 16(2) German Basic Law, which allows exceptionally for the extradition of German nationals, not read in the light of the European Union integration clause in Article 23(1) Basic Law - Complaint of violation of the democratic principle put in perspective - Preservation of the statehood of Germany - Lack of proportionality in and procedural defects of the implementing Act

\section{INTRODUCTION}

There were high hopes regarding the outcome of the judgment of the Bundesverfassungsgericht, the German Federal Constitutional Court, of 18 July 2005. ${ }^{1}$ However, the decision of the Karlsruhe judges was rather disappointing. It did not provide any new insights into the future of the European integration 'entity', of which still only one thing is known for sure: it exceeds by far the status of a 'classic' international organization, but it has, at the same time, not reached the level of statehood yet. According to a linguistic invention of the Federal Constitutional Court, it must therefore live under the term 'Staatenverbund' - an indeterminate designation which implies that it is situated somewhere at a midpoint between a confederation and a federal state. ${ }^{2}$

Because the European Union, and in particular the European Community as its most important unit, progressively discharges functions which not only concern minor aspects of the whole array of public tasks, but also those which are located close to the pillars of statehood of its member states, time and again tensions arise between these and the Union. It stands to reason that criminal law falls in the latter category. It is therefore understandable that the Federal Constitu-

* Professor of Public Law, International and European Law, Humboldt University, Berlin.

${ }^{1}$ Reprinted in EuGRZ (2005) p. 387.

${ }^{2}$ Entscheidungen des Bundesverfassungsgerichts (BVerfGE) 89, 155, at 184, 190. The English translation provided by 33 International Legal Materials (1994), p. 388 at 423, speaks of an intergovernmental community'. 
tional Court devoted intense attention to the first case in which it had to assess the European Arrest Warrant (EAW).

The most prominent characteristic of the EAW, which has its legal foundation in the Framework Decision of the Council of 13 June 2002 on the European Arrest Warrant and the surrender procedures between member states, ${ }^{3}$ lies in the duty of states to execute a foreign sovereign act, i.e., an arrest warrant, 'on the basis of the principle of mutual recognition' (Article 1(2)). ${ }^{4}$ However, this is not a purely technical operation. ${ }^{5}$ The execution can - or must - be refused under the circumstances specified in Articles 3 and 4 of the Framework Decision. Accordingly, even under the new regime, a formal procedure is required in the requested state to reach a decision on the surrender of the person sought. Nonetheless, the EAW is a legal instrument that is based upon a high level of confidence in the reciprocal relationships among the EU member states. Proceedings can be expedited because, to arrest a person with a view to his/her later surrender, no additional national arrest warrant is required based on data provided by the requesting state.

Other remarkable features of the EAW should be highlighted. An EAW can also be issued for nationals of a requested state. The requirement of double criminality has been dropped with regard to 32 categories of offences; in this case, the offence must be punishable in the requesting state by a custodial sentence or a detention order for a maximum period of at least three years (Article 2(2) of the Framework Decision). The requested state has no political discretion. ${ }^{6}$ The traditional exception clause of 'political offence' has also been abandoned. Notwithstanding these gains in efficiency, judicial protection should not be curtailed. The EAW is intended to avoid unnecessary bureaucratic encumbrances, but should not adversely affect the rule of law, even though one of its objectives is to intensify the combat on terrorism.

As a legal act, in the sense of Article 34(2)(b) EU, the Framework Decision lacks direct applicability although, like a directive under Article 249(3) EC, it is

${ }^{3}$ Of 18 July 2002, 2002/584/JHA, Official Journal of the European Communities L 190/1.

${ }^{4}$ On the drafting process see, in particular, document 15/1718 of the German Bundestag of 15 Oct. 2003; further Nicola Vennemann, 'The European Arrest Warrant and Its Human Rights Implications', 63 Zä̈RV (2003), p. 102 at p. 104-108, and Jürgen Jekewitz, 'The Action of the European Union to Combat Terrorism', in: Société Française pour le droit international (ed.), Les nouvelles menaces contre la paix et la sécurité internationales, Paris 2004, p. 77 at p. 77-82.

${ }^{5}$ According to $\$ 78$ of the International Assistance in Criminal Matters Act (Gesetz über die internationale Rechtshilfe in Strafsachen, IRG) the general extradition procedure is applicable unless the EuHbG has introduced special provisions. Consequently, in view of Art. 104(2) BL, detention for purposes of surrender must be determined by a judicial decision ( $\$ \$ 15,16$ IRG). The concept of a 'system of free movement of judicial decisions in criminal matters', as it appears in para. 5 of the preamble of the Framework Decision, is a bureaucratic monster.

${ }^{6}$ As far as terminology is concerned, the Framework Decision prefers the two concepts of 'issuing Member State' and 'executing Member State'. In the following, for the sake of convenience, we shall stick to the traditional terminology: 'requesting state' or 'requested state'. 
binding on the member states as to the result to be achieved. Consequently, it had to be tranposed into German law. This was done through the European Arrest Warrant Act (Europäisches Haftbefehlsgesetz, EuHbG), ${ }^{7}$ which contains provisions amending the International Assistance in Criminal Matters Act (Gesetz über die internationale Rechtshilfe in Strafsachen, IRG). The proceedings conducted against the applicant were founded on those provisions which had formed part of the IRG since July 2004.

It is common knowledge that initially the extradition of a German national to a foreign state ('Ausland') was forbidden absolutely (Article 16(2), first clause, of the Basic Law (BL)). The $47^{\text {th }}$ Amendment to the Basic Law, adopted in $2000,{ }^{8}$ softened this rigid prohibition. Pursuant to the newly inserted second clause in Article 16(2) BL

Different rules may be enacted for extradition to a Member State of the European Union or to an international court, provided that the rule of law (rechtsstaatliche Grundsätze) is safeguarded.

Thus extradition (or surrender) of a German national to just any third state is not allowed. Moreover, the fact that a state is a Contracting Party to the European Convention on Human Rights (ECHR) or to the International Covenant on Civil and Political Rights is not considered as a sufficient basis for extradition. In fact, the judicial systems in several of the 46 states parties to the ECHR give rise to serious concerns. ${ }^{9}$ The EuHbG was based on the new clause and was hence designed to establish the conditions for the extradition/surrender of German nationals to European Union member states, all of which can be considered as being particularly trustworthy. The structural norm of Article $6 \mathrm{EU}$ constitutes the pivotal element in this regard. According to the view of the Federal Constitutional Court, the attempt by the German legislature to regulate the relevant issues failed because it did not sufficiently take account of the principle of proportionality.

7 Of 21 July 2004, Bundesgesetzblatt (BGBl.) 2004 I, p. 1748. On this Act see Heiko Ahlbrecht, 'Freier Personenverkehr innerhalb der Europäischen Union in Auslieferungssachen - die Umsetzung des Europäischen Haftbefehls in das deutsche Rechtshilferecht', Strafverteidiger (2005) p. 40-47; Lyane Sautner, 'Die Vollstrechung eines Europäischen Haftbefehls nach dem EU-JZG', Österreichische Juristen-Zeitung (2005) p. 328-343; Helmut Seitz, 'Das Europäische Haftbefehlsgesetz', Neue Zeitschrift für Strafrecht (2004) p. 546-549.

${ }^{8}$ Of 29 November 2000, BGBl. 2000 I, p. 1633.

${ }^{9}$ Even with regard to the 'old' member states of the Council of Europe, the balance sheet is a fairly mixed one. In 2005, Italy was subject to 67 'convictions', France to 51 (against 81 for Russia and 270 for Turkey). Most of these convictions concerned procedural irregularities. 


\section{The Legal nature of Article i6(2) Basic LaW}

The Federal Constitutional Court chose as its point of departure a perspective which views the close co-operation of the EU member states within the framework of title VI EU essentially as a loss of substance in terms of the rule of law. The logic of a proceeding triggered by a constitutional complaint may be prone to suggest such an approach that, however, is not a necessary consequence thereof. The Court structured its reasoning pursuant to the model of an 'abstract review of norms' (abstrakte Normenkontrolle) without going into the factual details of the case at hand and its impact on the applicant. Nowhere did the Court assess whether the applicant was the actual victim of a specific interference with his fundamental rights. The violations found derive exclusively from the fact that the IRG, as amended by the EuHbG, does not correspond to the general requirements of Article 16(2), second clause, and 19(4) BL - and constitute therefore at the same time an infringement of Articles 2(1) and 20(3) BL. ${ }^{10}$

On the whole, the key issue for the Federal Constitutional Court was the decision enshrined in Article 16(2), first clause, BL, namely freedom from extradition (which should not be called freedom of extradition). It views Article 16(2), second clause, BL exclusively as an exception: 'This protection, however, can be restricted by law according to the second clause of that provision with regard to specific instances. ${ }^{11}$ This is all the Court was able to say about that guiding proposition. Thereafter the reader finds lengthy explanations about the values underlying the prohibition of extradition and its historical roots ${ }^{12}$ (yet, some decisive considerations are overlooked, in particular the arbitrary practice of Soviet courts vis-à-vis German prisoners of war after World War II). ${ }^{13}$ Likewise, the ensuing reflections on the content and scope of the provision ${ }^{14}$ remain exclusively confined to the negative consequences of Article 16(2), second clause, BL. The provision is characterized - and rightly so in terms of judicial technique - as establishing an 'authorization to interfere' with the substance of the ban on extradition which, beforehand, had been guaranteed without any reservation. It is highly significant that the Court raised the question as to whether the Amending Act of 2000 is

\footnotetext{
${ }^{10}$ Note of the editors: Art. 19(4) gives everyone whose personal rights are violated by a public authority recourse to a court; Art. 2(1) holds that everyone has the right to freely develop his/her personality insofar as the rights of others are not violated or the constitutional order or morality are not offended; Art. 20(3) states that legislation is subject to the constitutional order and that the executive and the judiciary are bound by law and justice.

${ }^{11}$ Section B. I. 1.

${ }^{12}$ Section B. I. 1. a). See the criticism of Judge Lübbe-Wolff in her dissenting vote.

${ }^{13}$ Some indications thereon emerged during the deliberations of the Parliamentarian Council, the body which drafted the Basic Law, see 1 Jahrbuch des Öffentlichen Rechts, Neue Folge (1951), p. 169.
}

${ }^{14}$ Section B. I. 1. b). 
unconstitutional on account of a violation of Article 79(3) BL, the 'eternity clause' of the Basic Law. ${ }^{15}$

To be sure, this hypothesis was rejected in a few sentences. However, the reader will not fail to notice that in a subsequent fairly arid section, which deals with the insertion of the EAW in the process of integration, the Court confined itself essentially to noting that the member states largely renounced their political discretion in matters of extradition by opting for close co-operation in criminal matters with a view to establishing an area of freedom, security and justice. It can be inferred from the following explanatory comments, which underline that co-operation is intended to support the 'process of integration (Zusammenwachsen) and the opening of the borders for persons, goods, services, and capital', that the Court quite obviously did not do justice to the new political impetus provided by the Maastricht Treaty more than ten years ago and that it remains stuck in the traditional economic logic of the EEC Treaty. It is perfectly in consonance with this approach that thereafter the Court again raised the issue of a possible infringement of Article 79(3) BL by (exceedingly far-reaching) 'Entstaatlichung' (abandonment of sovereign powers affecting statehood). ${ }^{16}$ Article 23(1) BL, which, inter alia, states that 'To realize a unified Europe, Germany participates in the development of the European Union', is mentioned only as a limit to integration, when the Court referred to the principle of subsidiarity laid down therein.

A correct interpretation, which would have taken into account the fundamental decisions on the future development of the German polity in its constitution, would have led to a different orientation. As we have seen, Article 23(1) BL states explicitly that the Federal Republic of Germany 'participates in the development of the European Union'. In 1992/93, when the European Union was created as the political framework for the then existing three European Communities, it was the openly declared objective of all member states to strengthen the links existing among them beyond a purely economic dimension. The introduction of Union citizenship, together with the political rights flowing therefrom, provides ample evidence for those intentions. Likewise, police and judicial co-operation in criminal matters, which was agreed upon already at that time, was to be an integral element of the political project which has now been intensified in qualitative terms. However, the structural link between Article 23(1) BL and Article 16(2), second clause, BL does not appear anywhere in the reasoning of the Court. Furthermore, the latter provision, which is not marred by any defect of unconstitutionality and therefore is a perfectly valid constitutional building block, should have been read as a constitutional directive on account of its affirmation of European (judicial) co-operation.

\footnotetext{
15 Section B. I. b) aa).

16 Section B. I. 1. b) cc).
} 
Instead, the Court treated the two clauses of Article 16(2) BL as being of unequal weight. It perceived the second clause rather as an anomaly, as a mere limitation, while for it the value substance is embodied exclusively in Article 16(2), first clause, BL. However, the second clause is significantly different from the majority of the other limitation clauses in the Basic Law. Those other clauses generally do no more than authorize in general terms restrictions of fundamental rights, whereas Article 16(2), second clause, BL proclaims to be an instrument for the realization of the objectives stated in Article 23(1) BL. Consequently, the judicial assessment followed a line of which the primary signposts are constituted by the statehood of Germany and its system of judicial protection, instead of reflecting on the opening which the German constitutional system experienced in 1993 through the introduction of Article 23(1) BL.

It stands to reason that we do not wish to engage here in naive Euro-euphoria. Not everything that bears the label 'European' is good for that sole reason. ${ }^{17}$ But it matters decisively whether a fundamental right is restricted on grounds flowing from current day-to-day policies or whether long-term, structural aims are being pursued which have been approved by constitutional amendment. In this regard, the judgment suffers from a gap in its reasoning, leaving the reader unsatisfied.

\section{The substantive CRITICISM OF the EuHbG}

\section{Duty to observe factual developments}

There is no doubt that to authorize extradition/surrender to a foreign judicial authority amounts to interference in a fundamental right. The parliamentary bodies, acting as constitutional legislature, clearly acknowledged their preoccupation with the rights of the persons concerned by providing that extradition is permissible only if 'principles of the rule of law are complied with'. According to the general rules shaped by the case-law of the Federal Constitutional Court over decades, the principle of proportionality is one of the main parameters that must be respected. ${ }^{18}$ Consequently, the ensuing considerations of the Court deserve full support. Yet the Court made a slightly misleading comment when it contended that the legislative bodies themselves have to examine whether the relevant 'requirements under the rule of law are fulfilled by the requesting authorities. ${ }^{19}$ As rightly pointed out by Judge Lübbe-Wolff in her dissenting opinion, ${ }^{20}$ the task of monitoring

${ }^{17}$ However, the criticism by Bernd Schünemann, 'Europäischer Haftbefehl und EUVerfassungsentwurf auf schiefer Ebene', Zeitschrift für Rechtspolitik (2003) p. 185-189, seems to be largely overstated.

${ }_{18}$ See ultimately BVerfGE 110,1 , at 28 et seq.; 141, at 163 et seq.; 177, at 193 et seq.; 226, at 262 et seq.; BVerfGE 109, 96, at 111 et seq.

${ }^{19}$ Section I. 1. c) aa).

${ }^{20}$ Section 4. 
whether these requirements are fulfilled in individual cases cannot be incumbent upon the legislature, both on factual and institutional grounds. One may hopefully assume that the Court did not suggest that a system has to be established similar to that provided for in Article 16a(2) and (3) BL. ${ }^{21}$ It is true, on the other hand, that blind faith in the rule of law in the other member states of the EU also is not the right solution. If a considerable deterioration of the essential procedural guarantees should occur in another country, $\$ 73$ IRG would become applicable in any event. ${ }^{22}$ According to this provision, judicial assistance is prohibited if it should 'contradict essential principles of the German legal order'. This precept is in perfect harmony with the case-law of the Federal Constitutional Court. An extradition jeopardizing indispensable constitutional principles to the detriment of the person concerned would in any event be unlawful, not only under German law, ${ }^{23}$ but also under Article $6 \mathrm{EU}$, the key principle of the entire EU legal order. Furthermore, as the Court rightly pointed out, in such a situation the legislature should enact by statute general measures of protection, irrespective of whether a proceeding under Article $7 \mathrm{EU}$ has been set in motion. ${ }^{24}$

The applicant had raised two principled complaints against the relevant provisions of the IRG as amended by the EuHbG. On the one hand, he invoked a violation of the democratic principle inasmuch as the European Parliament (EP), in accordance with Article 39 EU, had only been consulted on the Framework Decision. On the other hand, the applicant contended that the EAW was a measure exceeding the scope of Article 23(1) BL, and thereby contributed to an 'Entstaatlichung' of Germany. The Court rejected both complaints.

\section{Democratic deficit}

The Federal Constitutional Court dismissed the complaint of a violation of the democratic principle fairly summarily. It observed that, within the third pillar, the legislative bodies of the member states 'retain the political power of determination within the process of implementation, if necessary by refusing implementation. ${ }^{25}$ The concerns raised certainly could have been dealt with in a more appropriate

${ }^{21}$ Note of the editors: the first section of Art. 16 a proclaims the right of asylum for persons persecuted on political grounds, the second section makes an exception for persons coming from member states of the European Union or from other states in which the application of the Geneva Convention on refugees or the European Convention on Human Rights is ensured. These latter countries must be determined by an act of parliament which needs the consent of the second chamber, the Bundesrat. Art. 16 a(3) adds that such an act can also declare other countries 'safe' if it seems to be guaranteed that neither persecution on political grounds nor inhuman or derogatory punishment and treatment takes place.

${ }^{22}$ See also $\$ 49$ (1) No. 2 IRG.

${ }^{23}$ BVerfGE 75 , 1, at 19.

${ }^{24}$ Section B. I. 1. c) aa).

${ }^{25}$ Section B. I. 1. c) bb). 
way. Applying general principles of international and constitutional law to the third pillar, one may find it indeed truly exceptional that an agreement becomes binding before being approved by the competent parliamentary bodies. According to the model reflected in Article 59(2) BL, which is common to most states in Europe, important international agreements require parliamentary consent before the organ entrusted with the power of external representation may proceed to ratification (or other forms of acceptance) under international law. There can be no doubt that a decision on a simplified regime of extradition/surrender constitutes an important question since, on account of it, a fundamental right - protection against extradition - suffers a significant restriction. Through the system introduced by the EAW, the citizen is subject to the criminal jurisdiction of foreign states. Additionally, with regard to 32 groups of offences, the individual is deprived of the traditional guarantee that an offence must be punishable in both states, i.e., also in one's own country, before extradition can be granted.

It is obvious that through the adoption of the Framework Decision the parliaments of the member states were presented with a fait accompli, in any event regarding the essential elements of the EAW, since they were only authorized to determine the modalities of implementation in accordance with respective national legal systems. To admonish them to refuse, if necessary, the requisite 'Union loyalty' provides no answer to the problem, as is convincingly demonstrated by Judge Lübbe-Wolff. ${ }^{26}$ In the present configuration, however, it can be argued without any major difficulty that the national legislatures gave their consent to the Framework Decision in advance. In the present context, the EU Treaty identifies the specific task to be fulfilled. The specified program of action in Article 31(2)(b) EU corresponds precisely to the requirements of legal certainty regarding transfers of competences defined by the Federal Constitutional Court in its Maastricht judgment. ${ }^{27}$ Article 32(2)(b) states that, within the framework of judicial co-operation in criminal matters, the member states agree to strive for the facilitating of extradition among them. This is a formulation that would even satisfy the requirements of Article 80(1) BL regarding the stipulation of provisions authorizing the enactment of (delegated) regulations. Had this provision been laid down in the EC Treaty, no one would have doubted that it corresponds to the principle of limited powers (compétences d'attribution). As long as the defining act of democratic legitimation is viewed in the approval of the treaties by the national parliaments, and as long as the exercise of public powers by organs made up of persons only indirectly legitimated in democratic terms is accepted, it does not matter whether a genuine transfer of sovereign powers has taken place which leaves no room whatsoever for national authorities, or whether a power of inter-

\footnotetext{
${ }^{26}$ Section 5 of her dissenting opinion.

${ }^{27}$ BVerfGE 89, 155, at 189 et seq.
} 
governmental action is established under which the national legislative organs can still discharge - modest - functions of transposition and execution. On the contrary, in this latter case the interference in the democratic substance does not have the same degree of intensity.

On the other hand, specifically in the international field one should not overrate the decision-making power enjoyed by the Bundestag and the Bundesrat. It is certainly true that treaties of the kind specified in Article 59(2) BL require parliamentary approval before the formal act of acceptance under international law may be effected. But one should soberly take note of the fact that because of the complexity of the processes of negotiation in the relevant international fora, things boil down to the following proposition: les jeux sont faits once the texts have been drawn up. Parliaments are confined to an 'ex post assessment'. ${ }^{28}$ Consequently, they should influence the relevant negotiating processes and make their views known in due time. Only then are they capable of co-shaping international legislative projects. As its premise, this has accurate information, structured according to the importance of the individual projects, which according to the law on the books seems to be secured by the Act on the Co-operation between the Federal Government and the German Bundestag in Matters of the European Union, ${ }^{29}$ and the Act on the Co-operation between the Federation and the Länder in Matters of the European Union. ${ }^{30}$ Through the channels of information institutionalised by these laws, the parliamentarian bodies can exert influence, regardless of whether the draft measures are located in the field of Community law or in the 'third pillar'.

However, it seems obvious that in this case the national parliaments in all the then existing 15 member states failed to live up to legitimate expectations. Only in this way can it be explained that a number of vague and indeterminate offences such as computer-related crimes, racism and xenophobia as well as sabotage were included in the Framework Decision as offences for which the requirement of double criminality is lifted. ${ }^{31}$ As far as can be seen, none of the thousands of

${ }^{28}$ Christian Tomuschat, 'Der Verfassungsstaat im Geflecht der internationalen Beziehungen', 36 Veröffentlichungen der Vereinigung der Deutschen Staatsrechtslehrer (1978), p. 7 at p. 31.

29 Of 12 March 1993, BGBl. 1993 I, p. 311.

30 Of 12 March 1993, BGBl. 1993 I, p. 313.

${ }^{31}$ In legal doctrine many voices have criticized the inclusion of these three classes of criminal conduct in the list of offences for which the requirement of double criminality is abolished; see Ahlbrecht, supra n. 7, who speaks of 'despise' of a 'liberal criminal policy which had grown in Europe over centuries'; Ewa M. Guzik Makaruk, "Ne bis in idem”. Europäischer Haftbefehl und der Verfassungsentwurf für Europa aus polnischer Sicht', Zeitschrift für die gesamte Strafrechtswissenschaft (ZStW) 116 (2004), p. 372 at p. 374; Gustavo Pansini, 'La réception du mandat d'arrêt européen en Italie. Brèves réflexions', in: Marie-Elisabeth Cartier (ed.), Le mandat d'arrêt européen (Bruxelles 2005) p. 179 at p. 181; Schünemann (footnote 16), p. 188. Criticism has also been voiced because of the lack of precision of the list in Art. 2(2) of the Framework Decision, see Michel 
parliamentarians in Europe, who were all informed in some way or another, protested against that list of horrors nor called upon his or her government to deny consent. The ministers of justice are to be blamed as well since they simply let their staff act - without being aware of the delicate nature of those offences, which permit the most diverse interpretations and which can hardly be traced back to a common European stock of values. In the inundating floods of European activities, what seems to be lost is a compass for identifying the essential threats to the freedom of the citizen.

The above considerations, which emphasize the preciseness of the normative program laid down in Article 31(1)(b) EU, do not resolve the problem of democratic legitimacy. The Maastricht judgment, however, already concluded that provisionally, as long as the 'Staatenverbund' exists, compromises must be accepted. ${ }^{32}$ On the one hand, a democratic deficit is being complained of but, on the other, as soon as the powers of the European Parliament are decisively enlarged and deepened, invariably the objection of 'Entstaatlichung' arises. The Federal Constitutional Court takes this objection very seriously, using it as a legitimate concept of legal argumentation. Precisely for that reason, it will be necessary to get acquainted with the idea of living in certain provisional settings for a long time to come - il n'y a que le provisoire qui dure - which exactly corresponds with the factual state of development of the European Union. National sovereignty and Community (Union) power must be brought into a delicate balance. One should acknowledge that this system of different levels of governance by its very nature cannot have the consistency and straightforwardness of national constitutional systems. The dangers lie less in a denial of democratic decision-making power to the detriment of the demos, but rather in a lack of transparency which leads to a blurring of accountability. Moreover, many national parliaments do not seem to have noticed how influential they can be and the responsibility they have to shoulder in shaping the political processes in Europe through the different mechanisms which permit them to bring pressure on their governments. ${ }^{33}$

\section{'Entstaatlichung'}

The Federal Constitutional Council devoted considerable attention to the complaint of 'Entstaatlichung' ${ }^{34}$ As already mentioned, this complaint eventually did

Massé, 'La decision-cadre', in: Le mandat d'arrêt européen, p. 47 at p. 59; Cristina Mauro,'Réflexions à propos de la loi introduisant le mandat d'arrêt européen en France', ibid., p. 201 at p. 210 ('catégories assez floues').

${ }^{32}$ BVerfGE 89,155 , at 186 et seq.

${ }^{33}$ From the very beginning, the Danish Parliament, the Folketing, has been a laudable - and sometimes disturbing - exception.

${ }^{34}$ Section B. I. 1. b) cc). 
not find a positive echo with the judges although it was accepted as topos arguendi. In the relevant section, the Court drew firm boundary lines, essentially in accordance with the Maastricht judgment. ${ }^{35}$ The state has to remain entrusted with tasks of 'substantial weight'; essential public tasks cannot be abandoned. It is hardly understandable, however, why in this connection, with an almost threatening tone, the judges rejected a 'general harmonization of the criminal legal systems of the Member States'. Why is it not legitimate, within a 'Staatenverbund, which conceives of itself as a polity with commonly shared values, to pursue the harmonization of criminal law designed precisely to uphold those common values? ${ }^{36}$ Looking at the list of offences set out in Article 2(2) of the Framework Decision, one comes indeed to the conclusion that broad agreement exists about many breaches of the law that deserve to be punished. Whether those breaches are sanctioned by way of 'limited mutual recognition', namely through mutual judicial assistance on the basis of the EAW, or by way of 'general harmonization of the criminal systems of the Member States' should make no difference with regard to German constitutional law. ${ }^{37}$ Yet at the same time, as already mentioned, the list of Article 2(2) of the Framework Decision was extended in an almost 'criminal' way, a monumental failure of the responsible German constitutional organs, which can hardly be attributed to the relevant legal basis of the Framework Decision. ${ }^{38}$

On the whole, section B. I. 1. b) cc) of the judgment clearly shows to what high degree subjective considerations can colour the judgments on the preservation of the 'statehood' of Germany. On many points the reader is reminded of the German debate on whether the progressive transfer of tasks and powers from the Länder to the Federation has undermined, in a slow process of erosion, the 'federality' of the system. Undeniably, the process of European integration has protruded close to the core elements of statehood. But it remains that the institutions of the Union are vested only with limited competences and that, to this very date, the European Parliament has been denied comprehensive legislative powers. Thus, the Union has to operate within a legal framework which exhaustively de-

35 BVerfGE 89, 155, at 186.

${ }^{36}$ See in this connection Sabine Gleß, 'Zum Prinzip der gegenseitigen Anerkennung', 116 ZStW (2004), p. 353 at p. 361, who convincingly demonstrates that the guarantees afforded to the individual are strengthened precisely through harmonization of criminal law; her views are shared by Isabelle Jégouzo, 'Le mandate d'arrêt européen, acte de naissance de l'Europe judiciaire pénale', in: Le mandat d'arrêt européen (Cartier, supra n. 31), p. 33 at p. 39; Gonzalo Quintero Olivares, 'Le mandat d'arrêt européen dans la perspective européenne d'unification de la justice pénale et la réglementation espagnole, ibid., p. 163 at p. 164-172.

37 This is also recognized by Bernd Schünemann, 'Fortschritte und Fehltritte in der Strafrechtspflege der EU', 151 Goltdammer's Archiv (2004), p. 193 at p. 197 et seq.

${ }^{38}$ Schünemann's contention (supra n. 37, at p. 207) that the Framework Decision went beyond its scope ratione materiae and lacked therefore any binding force, will not be discussed here. In any event, the FCC did not express any doubts as to the validity of that act. 
fines its powers ratione materiae. It does not enjoy Kompetenz-Kompetenz. It is not capable of unilaterally extending the space of action allotted to it. Lastly, the member states still have the final word, a fact which is reflected tellingly in the power of withdrawal formally recognized in the draft European Constitutional Treaty (Article I-60). ${ }^{39}$ Against the declared will of all of its member states, the Union has no claim to statehood. Accordingly no 'Entstaatlichung' can have taken place to the detriment of Germany - and of course to the other member states.

\section{Proportionality}

Regarding the central issue of proportionality, one can easily follow the distinction made by the Federal Constitutional Court between offences with a defining link of domestic territoriality and offences with a defining link to a foreign country. ${ }^{40}$ Invariably, criminal prosecution abroad constitutes a sacrifice for a German national. However, if he or she goes to a foreign country and commits an offence there, it simply corresponds to elementary logic and is in line with international law, according to which in criminal matters the principle of territoriality still dominates, to conduct the proceedings where the victims have their residence and where witnesses and other evidence are easily accessible. ${ }^{41}$ It is a different matter altogether if the offence was perpetrated in Germany. One can hardly argue against the holding of the Court that in such instances judicial prosecution should take place, in principle, before German tribunals. It is striking, though, that the judgment lacks any detailed considerations elaborating on this fundamental distinction in respect to the case at hand. The facts as set out in the introductory part of the judgment mention 'visits of the applicant to Spain as well as meetings and telephone conversations with alleged perpetrators', i.e., acts in Spain, which in fact led the Audiencia Nacional in Madrid to issue the arrest warrant. According to the arrest warrant of the Hanseatic Court of Appeals of Hamburg of 15 October 2004 the applicant acted presumably in Spain, Germany and the United Kingdom' as 'the key figure of the terrorist network Al Qaeda'. This does not support the inference that a predominant link to Germany was present. Concerning mixed configurations, i.e., facts linked to both Germany and (an)other state(s), the Constitutional Court requires an actual balancing test in every individual case. ${ }^{42}$ But in casu, it does not follow its own criteria, notwithstanding the fact that in the context of a constitutional complaint attention must be focused primarily on the case at hand. Here again it emerges that the focus of the Federal Constitutional

${ }^{39}$ Official Journal of the European Union, C 310/1, 16 Dec. 2004.

${ }^{40}$ Section B. I. 1. c) cc).

${ }^{41}$ See also Cornelius Nestler, 'Europäisches Strafprozessrecht', 116 ZStW (2004), p. 336 at p. 338 et seq.

${ }^{42}$ Section B. I. 1. c) cc). 
Court was less on remedying the alleged violation of a fundamental right and more on making use of the case to carry out a comprehensive review of the relevant provisions of the IRG in the vein of a proceeding for the 'abstract control of norms'.

Eventually, after examining the compatibility of the EuHbG with the constitutional principle of proportionality, the Court concluded that the legislative bodies failed to avail themselves of the discretionary powers enjoyed by them for the protection of German nationals. Regarding cases having a domestic territorial link, Article 4(7)(a) of the Framework Decision is particularly pertinent. According to that provision, the execution of an arrest warrant may be refused if the offence was committed in whole or in part in the territory of the requested state. The same applies if domestically criminal prosecution has been initiated against a suspect (Article 4(2) of the Framework Decision), or if the judicial authorities of the requested state have decided not to commence a criminal proceeding on account of the offence underlying the arrest warrant, or to halt pending proceedings (Article 4(3) of the Framework Decision). No use whatsoever had been made of Article 4(7)(a) in the EuHbG, and the two other clauses were taken into account only to a limited extent. In the relevant German provision, $\$ 9$ No. 1 IRG, which deals with a number of obstacles to extradition under the title 'concurring jurisdiction', the halting of criminal investigations - an act on which the person concerned should in principle be able to rely - does not appear at all. Lastly, $\$ \$ 83 \mathrm{~b}$ No. 1 and 2 IRG, regarding the initiation of domestic proceedings and the decision not to commence proceedings of criminal prosecution, have been set forth only as discretionary powers. These are the specific deficits that prompted the Court to declare the EuHbG void.

In respect to Article 4(2) and (3) of the Framework Decision, it is somewhat difficult to understand whether there really was a failure to make use of the discretion granted by the European act. Apparently the Court holds that the grounds enunciated in those two provisions should have been established as compulsory obstacles to surrender and should not have remained purely discretionary powers (Kannbestimmungen). But the Court did not elaborate on this issue in any detail. ${ }^{43}$ Since proportionality is a constitutional principle binding on the executive and the judicial branches of government, it would have been preferable to rely on the consciousness of the competent authorities, by stressing that in case of termination of a prosecutorial investigation surrender should be refused as a rule. In that regard, the opinion of dissenting Judge Gerhardt is more persuasive than the decision of the Court.

${ }^{43}$ Section B. I. 1. d) bb). 
Regarding non-resort to the clause of Article 4(7)(a) of the Framework Decision, the gap in the IRG appears to be more serious at first glance than it is in reality. With respect to the majority of the offences listed in Article 2 of the Framework Decision, it appears almost inconceivable, given the principle of legality as it applies in Germany, ${ }^{44}$ not to witness at least the initiation of an investigation if a domestic connection is present. Otherwise, the competent prosecutorial authorities could be blamed for grossly failing to comply with their duties. If an investigation is commenced, $\$ 83 \mathrm{~b}$ Nos. 1 and 2 IRG were to become applicable. Even after an arrest warrant has been received from another European country, an additional German investigation may be initiated. ${ }^{45}$ The danger for a German to be surrendered on account of a crime committed in Germany appears, therefore, to be rather theoretical. At the most, some borderline cases may occur. Yet the case at hand provides no evidence for such a configuration, as was already pointed out.

Lastly, the question must be asked whether the reasons invoked by the Federal Constitutional Court, in particular the failure to transpose Article 4(7)(a) of the Framework Decision into the IRG, made it really imperative to come to a finding of unconstitutionality. Could the defect have been healed by way of an interpretation in conformity with European law? There should be no doubt that, in the same way a national statute enacted to transpose a Community directive must be interpreted in the light of that directive, ${ }^{46}$ national measures implementing a framework decision should be placed under the same methodological requirement. The ECJ embraced that approach recently in the Pupino case, ${ }^{47}$ and its holding corresponds fully to the doctrine of interpretation in conformity with international law as evolved by the Federal Court in its own case-law. Judge Gerhardt based his dissenting opinion, ${ }^{48}$ inter alia, on the Pupino judgment which was handed down shortly before the judgment of the Federal Constitutional Court, but to which, amazingly, the majority does not refer at all. To declare the entire law (EuHbG) unconstitutional has only a certain plausibility from the viewpoint of the Federal Constitutional Court. It believes that it found a gap in the system of judicial protection that threatens the freedom of the citizen. Regarding such a fundamental issue, it considered absolute legal clarity to be necessary, which can-

${ }^{44}$ According to this principle, the prosecutorial authorities are generally obligated to prosecute ex officio any criminal conduct ( $\$ 152(2)$ of the Code of Criminal Procedure).

${ }^{45}$ See Ahlbrecht, supra n. 7, at p. 46, who even maintains that in such circumstances it is urgently required to initiate a criminal proceeding under German criminal law.

${ }^{46}$ Court of Justice of the European Communities, case C-106/89, ECR 1990, I-4135, para. 8 - Marleasing; case C-334/92, ECR 1993, I-6911, para. 20 - Wagner, Miret; case C-91/92, ECR 1994, I-3325, para. 26 - Faccini Dori; see also Paul Craig/Graínne de Búrca, EU Law (Oxford 2003) p. 211 et seq.

47 Judgment of 16 June 2005, case C-105/03.

48 Section I. 1. 
not be obtained through references to the Framework Decision and the constitutional principle of proportionality. This line of reasoning is understandable, but finally does not convince inasmuch as domestically committed offences that could lead to surrender on the basis of an EAW constitute more a theoretical construct than a class of cases realistically conceivable. Consequently, it would have been preferable, as suggested by Judge Gerhardt, ${ }^{49}$ not to strike down the EuHbG in its entirety but to deny its applicability in certain classes of cases. The damage caused by the Court's decision is indeed considerable. Only a few days after the delivery of the judgment, newspapers reported that surrender procedures between Germany and Spain had ground to a halt. ${ }^{50}$ It will take a considerable time to carry out the requisite repair work.

\section{Procedural defects of the EuHbG}

The Federal Constitutional Court found another constitutional infringement, which is of a procedural character. It held that, contrary to $\$ 74 \mathrm{~b} I R G$, a remedy must be available against a decision granting surrender, a conclusion entailed by the fact that such a decision falls within the scope of Article 16(2) BL and does not concern political considerations outside individual entitlements only. ${ }^{51}$ That view is sustained by ample reasoning and can hardly be called into question, and yet it has shaky foundations as will be shown in the following.

The legislative authorities have failed to recognize that by laying down precise criteria for the refusal to comply with a request for surrender, the Framework Decision has fundamentally altered the pre-existing system. The legal situation becomes even more complex due to the fact that the surrender of every alien, and not only of a 'domestic alien' in the sense contemplated by $\$ 80$ (3) IRG, ${ }^{52}$ has aspects relevant in terms of fundamental rights. Any arrest, because it implies deprivation of liberty, interferes with the fundamental right under Article 2(2) BL; in any event Article 2(1) BL would apply. ${ }^{53}$ Following the premises of the Federal Constitutional Court, the legislature cannot confine itself to introducing new rules for German nationals; rather, the entire system has to be re-assessed. If in the future in surrender proceedings, two decisions were rendered, first a decision on admissibility and thereafter the authorization to extradite proper, both of which are subject to judicial challenge, fairly complex procedural configurations

${ }^{49}$ Section II.

${ }^{50}$ Die Welt, 23 July 2005.

${ }^{51}$ Section B. I. 2.

52 Essentially, a 'domestice alien' is an alien enjoying a stable right of sojourn in Germany.

53 Note of the editors: Art. 2(2) holds that freedom of the person is inviolable and may only be restricted pursuant to a statute, Art. 2(1) that everyone has the right to freely develop his/her personality. 
could result therefrom. Following the reasoning of the Court, it is obvious that far-reaching overlaps will occur inasmuch as in either proceeding the legal position of the person concerned has to be taken into account. Just a short glance at $\$ 83$ IRG on the one hand and $\$ 83 \mathrm{~b}$ IRG on the other shows the proximity between a decision on admissibility and the subsequent authorization to surrender.

Therefore the decision to maintain the double-track system under the regime of the EAW was a mistake. It seems that the German statute implementing the Framework Decision needs to be modified much more fundamentally than is suggested by the Court. To introduce two parallel and overlapping judicial procedures cannot be an ideal solution. In principle, the regime of the EAW is designed to concentrate the decision on a request for surrender in the hands of one single authority, namely a judicial body (see, in particular, Articles 6(2) and 15 of the Framework Decision). It therefore seems advisable to submit all determinations touching upon the fundamental rights of the persons concerned to judicial review, with a subsequent act of authorization to surrender exclusively dedicated to general questions of political expediency - at least if such questions still exist in an environment permeated by fundamental rights, and if the Framework Decision allows for such a double-track procedure. In that regard, considerable doubts exist.

One has to assume that Germany fell prey to a serious error relating to the concept of 'judicial authority' when it drafted the EuHbG. As precisely shown by the proceedings before the Federal Constitutional Court, with its preliminary stages in Hamburg, the opinion prevailed that a Ministry of Justice is a judicial authority as contemplated by the Framework Decision. The explanatory report to the bill says in simple terms that it was left to the member states to determine the competent national authorities. ${ }^{54}$ That statement is correct, but at the same time erroneous insofar as, with its unclear reference to the federal power for external relations under Article 32(1) BL, it seeks to maintain the pre-existing competence of the Federal Government. ${ }^{55}$ The English text of the Framework Decision speaks clearly of a judicial authority, i.e., an authority made up of judges, and likewise the French text, using the words 'autorité judiciaire', makes clear that an executive authority is not included. ${ }^{56}$ This result of a literal interpretation is confirmed by the teleology of surrender under the regime of the EAW. Political discretion is to be eliminated; the relevant decisions shall be made exclusively by judges. ${ }^{57}$ In this

${ }^{54}$ Bundestag document 15/1718, supra n. 4, at p. 10.

55 In Austria, that interpretation was not embraced, see Sautner, supra n. 7, at p. 329, 332.

56 The Spanish text speaks of 'autoridad judicial', and the Dutch text uses the concept 'rechterlijke autoriteit'.

${ }^{57}$ Mauro, supra n. 31, at p. 216 et seq., raises objections against certain modalities of the French statute of implementation. 
regard, a profound re-examination of the German law of implementation is necessary, a re-examination that cannot remain confined to the directives imparted by the Federal Court. ${ }^{58}$ The existing German regime is predicated on the misconception that the decision on admissibility, which lies in the hands of a Court of Appeals, constitutes no more than the first step in the process of surrender where the executive branch has the final word. The Court, too, proceeds from this concept, which is not in harmony with the general provisions of the Framework Decision.

\section{CONCLUDING OBSERVATIONS}

In the future, problems relating to the EAW will probably arise less on the grounds dealt with by the Federal Constitutional Court, but rather from fear of disrespect of the rule of law in one of the member states and from the threat of covert political persecution. Although in principle sufficient legal safeguards against such dangers are provided for (Article $6 \mathrm{EU}$ in conjunction with Article 1(3) of the Framework Decision and $\$ \$ 6(2), 73$ IRG), ${ }^{59}$ it will not be easy for the courts to affirm the existence of such negative conditions in another member state and to reject on that ground a request for surrender made through an EAW. It is also urgent that a review of the list of offences in Article 2(2) of the Framework Decision be made in order to sort the wheat from the chaff. Furthermore, it remains hard to understand why the guarantee of double criminality has been foregone. ${ }^{60}$ Essentially, this abandonment amounts to a mutual vote of mistrust. It is implicitly assumed that one of the member states has not shown the necessary zeal in combating certain phenomena of social interaction and therefore has to be 'disciplined'. Primacy is accorded to the interest in prosecution and punishment while the deliberate option of one of the member states for tolerance is viewed as less weighty. Specifically in a community of values, however, one may safely assume that a decision against criminalization does not flow from ideological aberrations or other forms of obscure theorem, but has solid foundations. In these respects, the Framework Decision can safely be said to be failing.

58 The statement in the explanatory report, Bundestag document 15/1718, supra n. 4, at p. 11, to the effect that the existing German system requires no systemic overhaul, would therefore appear to be less than well-reflected. Ahlbrecht, supra n. 7, at p. 42, reports that the German decision to maintain the existing system created considerable uneasiness in the EU and in some member states. Doubts were also voiced by Seitz, supra n. 7, at p. 547. Massé, supra n. 31, at p. 47, 54, states unequivocally that the EAW leads to a 'mise hors circuit des ambassades et des gouvernements' and that the procedure is now 'purement judiciaire'. The problem is not recognized by Jörg Schwalm, 'Le mandate d'arrêt en Allemagne', ibid, p. 101 at p. 108.

59 See Vennemann, supra n. 4, at p. 114-120.

${ }^{60}$ A hardly convincing attempt to justify the decision was undertaken in the explanatory report to the bill, Bundestag document 15/1718, supra n. 4, at p. 17. 
Having perused the judgment, the reader has definitely the impression that the Karlsruhe judges again wanted to make their views on the limits of European integration clear, but the case was not well suited for such a decision of principle. The initial stage had dramatic features by the issuance of an interim order in accordance with $\$ 32$ of the Act on the Federal Constitutional Court. Quite rightly the Court issued that injunction since, in view of the complaints raised, it could not be foreseen whether the applicant might suffer irreparable damage. However, the further course of the proceedings yielded few elements of true tension. Consequently, it certainly would have been more sensible to render a decision more closely geared to the case at hand instead of declaring the entire EuHbG null in one big bang. Among the positive aspects in this case is the lesson taught to the legislative bodies that in the process of implementing Union and Community law they must not act as servile machines of execution and that, on the contrary, they have to shoulder an autonomous responsibility within certain limits, which are to be carefully identified in each individual case. 